\title{
Innowacyjne środki myjąco-konserwujące i oleje ochronne
}

\section{Innovative cleaning and conservation chemicals and protective oils}

\author{
Barbara Gaździk¹, Roman Kempiński², Zbigniew Paćkowski², Kamil Pomykała \\ ${ }^{1}$ Instytut Nafty i Gazu - Państwowy Instytut Badawczy \\ ${ }^{2}$ Pachemtech Sp. z o.o.
}

\begin{abstract}
STRESZCZENIE: Środki ochrony czasowej, w tym środki myjąco-konserwujące i oleje ochronne, odgrywają ważną rolę w procesie produkcji, magazynowania i transportu wyrobów metalowych, decydując o utrzymaniu ich właściwości technicznych oraz przydatności użytkowej w wymaganym okresie. Przyczyną korozji wyrobów metalowych są: tlen, woda, kwasy, zmiany temperatury, kwaśne opary, skład chemiczny wyrobu, jakość powierzchni oraz rodzaj obróbki, której był poddany metal. W publikacji przedstawiono metodykę oraz wyniki badań laboratoryjnych innowacyjnych produktów opracowanych w Instytucie Nafty i Gazu - PIB, we współpracy z firmą Pachemtech, w ramach projektu Innowacyjne środki chemiczne z udziałem zmodyfikowanej imidazoliny dla przemystu rafineryjnego, wydobywczego ropy naftowej, hutniczego i maszynowego, dofinansowanego ze środków Narodowego Centrum Badań i Rozwoju w ramach Programu Badań Stosowanych. Przeprowadzone badania wykazały bardzo dobre właściwości fizykochemiczne i funkcjonalne środka myjąco-konserwującego Pachem-SMK-4917 do mycia wyrobów metalowych oraz do międzyoperacyjnej ochrony przeciwkorozyjnej. Badany środek jest bezzapachową cieczą o jasnej barwie, niskiej lepkości, około $4 \mathrm{~mm}^{2} / \mathrm{s} \mathrm{w} 20^{\circ} \mathrm{C}$, oraz temperaturze zapłonu powyżej $100^{\circ} \mathrm{C}$. Wykazuje niskie napięcie powierzchniowe i niski punkt anilinowy, co zapewnia wysoką efektywność mycia wyrobów metalowych. Badania wykazały, że środek Pachem-SMK-4917 tworzy cienki film, o grubości 0,5 $\mu$ m, odporny na działanie zmiennych temperatur, wilgoci, wody i chlorków. W wyniku badań właściwości przeciwkorozyjnych w wilgotnej atmosferze (100\%) w temperaturze $49^{\circ} \mathrm{C}$ na płytkach ze stali stwierdzono, że pierwsze oznaki korozji pojawiły się po 336 godzinach, podczas gdy w przypadku próbki zerowej już po 6 godzinach. Przeprowadzone badania wykazały bardzo dobre właściwości fizykochemiczne i funkcjonalne oleju ochronnego Pachem-OO-4018 do ochrony czasowej (8-15 miesięcy) przed korozją atmosferyczną powierzchni wyrobów metalowych podczas ich składowania, transportu i użytkowania. Badany olej charakteryzuje się niską lepkością, około $5 \mathrm{~mm}^{2} / \mathrm{s} \mathrm{w} 40^{\circ} \mathrm{C}$, temperaturą zapłonu powyżej $100^{\circ} \mathrm{C}$ oraz niską temperaturą płynięcia - poniżej $-40^{\circ} \mathrm{C}$. Olej ten na powierzchni metalu tworzy cienką, o grubości $2 \mu \mathrm{m}$, miękkopowłokową warstwę ochronną o wysokiej trwałości w czasie i zdolności do wypierania wody. W czasie badań właściwości przeciwkorozyjnych oleju Pachem-OO-4018 w wilgotnej atmosferze $(100 \%) \mathrm{w}$ temperaturze $49^{\circ} \mathrm{C}$ na płytkach ze stali stwierdzono, że pierwsze oznaki korozji pojawiły się po 768 godzinach. Olej wykazuje wysokie właściwości przeciwkorozyjne w stosunku do stali, miedzi, brązu cynowo-cynkowo-ołowianego i brązu aluminiowego, posiada również bardzo dobre właściwości deemulgujące.
\end{abstract}

Słowa kluczowe: ochrona czasowa, środek myjąco-konserwujący, olej ochronny, korozja, powłoka ochronna.

ABSTRACT: Long lasting protection measures, including cleaning and conservation chemicals and protective oils, play an important role in the production, storage, and transport of metallic products, maintaining their technical properties and usability for the required duration. Corrosion is caused by the presence of oxygen, water, acids, temperature changes, acid vapors, high humidity and it depends on chemical composition of the product, surface quality, and the type of treatment provided to the metal. The article presents the research methodology and the laboratory test results of the innovative products: cleaning and conservation chemicals and protective oils, developed at the Oil and Gas Institute - National Research Institute in cooperation with Pachemtech Ltd. as part of the Project Innovative chemicals with modified imidazoline for the refinery, oil field, metallurgy and machinery industries, co-financed by the National Center for Research and Development as part of the Applied Research Program. The tests showed very good physicochemical and functional properties of PACHEM-SMK-4917 - a cleaning and conservation chemical for metal products and for corrosion protection between their processing. The tested chemical is a light-colored, odorless liquid, with low viscosity of about $4 \mathrm{~mm}^{2} / \mathrm{s}$ at $20^{\circ} \mathrm{C}$ and with a high flash point above $100^{\circ} \mathrm{C}$. It has low surface tension and a low aniline point, which ensures high efficiency of cleaning metal elements. Studies have shown that PACHEM-SMK-4917 forms a thin film with a thickness of $0.5 \mu \mathrm{m}$, resistant to temperature variations, moisture, and water. Tests of anti-corrosive properties on steel plates in a humid atmosphere $(100 \%)$ at $49^{\circ} \mathrm{C}$ showed that the first signs of corrosion appeared after 336 hours, while for the reference zero sample after 6 hours. The tests also showed very good physicochemical and functional properties of Pachem-OO-4018 - a protective oil, for temporary protection (8-15 months) against atmospheric corrosion of metal elements during storage, transport and use. The tested oil has a low viscosity of about $5 \mathrm{~mm}^{2} / \mathrm{s}$ at $40^{\circ} \mathrm{C}$, a flashpoint above $100^{\circ} \mathrm{C}$

Autor do korespondencji: B. Gaździk, e-mail: barbara.gazdzik@inig.pl

Artykuł nadesłano do Redakcji 28.09.2018 r. Zatwierdzono do druku 3.06.2019 r. 
and a low pour point of $-40^{\circ} \mathrm{C}$. The tested oil creates a thin, $2 \mu \mathrm{m}$-thick, soft protective film on the surface of the metal, characterized by high durability and high hydrophobic properties. The tests of anti-corrosive properties of Pachem-OO-4018 oil on steel plates in a humid atmosphere $(100 \%)$ at $49^{\circ} \mathrm{C}$ showed that the first signs of corrosion appeared after 768 hours. The oil has high anti-corrosive properties in relation to steel, copper, tin-zinc-lead bronze and aluminum bronze; it also shows very good demulsifying properties.

Key words: time protection, cleaning and conservation chemical, protective oil, corrosion, protective coating.

\section{Wstęp}

Instytut Nafty i Gazu - Państwowy Instytut Badawczy i współpracująca z nim firma Pachemtech zrealizowały projekt Innowacyjne środki chemiczne z udziałem zmodyfikowanej imidazoliny dla przemystu rafineryjnego, wydobywczego ropy naftowej, hutniczego i maszynowego, dofinansowany ze środków Narodowego Centrum Badań i Rozwoju w ramach Programu Badań Stosowanych, Ścieżka A. W zakresie projektu zostały opracowane m.in. technologie innowacyjnego środka myjąco-konserwującego Pachem-SMK-4917 i oleju ochronnego Pachem-OO-4018.

Korozja jest przyczyną niszczenia wyrobów żeliwnych i stalowych. Wyroby metalowe, które uległy korozji, tracą swoje właściwości użytkowe i muszą być zastąpione nowymi, co znacznie zwiększa koszty. Elementy konstrukcji budowlanych, części maszyn oraz inne wykonane z metali wyroby ulegają korozji ze względu na niestabilność metalu. Istnieje zależność między szybkością korozji metali, a wpływem środowiska. Obecność tlenu, wody, kwasów, chlorków, zmiany temperatury, kwaśne opary, duża wilgotność, pot z rąk i inne szkodliwe substancje powodują korozję (Gaździk, 2016). Ważnym czynnikiem wpływającym na przebieg procesów korozji jest skład chemiczny wyrobu, znacznie łatwiej ulegają korozji stale węglowe niż stopowe, duży wpływ ma również jakość powierzchni i stopień przetworzenia metalu oraz rodzaj obróbki, której był poddany metal (Antosz i Ptak, 2017). Jedną z ważniejszych przyczyn korozji stanowi czas i związane z tym procesy starzenia się metalu i powłok ochronnych.

W produkcji wyrobów metalowych czasowa ochrona metali przed korozją odgrywa istotną rolę. Ochrona czasowa obejmuje zespół czynności zabezpieczenia wyrobów z metalu przed korozją $\mathrm{w}$ czasie procesu ich wytwarzania pomiędzy kolejnymi operacjami (mycie, czyszczenie i konserwacja międzyoperacyjna) oraz na czas wielomiesięcznego lub wieloletniego magazynowania i transportu (Tate i Beale, 2010; Żabicki, 2012).

\section{Charakterystyka środków do ochrony czasowej}

\section{Środki myjąco-konserwujące}

Podczas produkcji wyrobów metalowych ma miejsce międzyoperacyjne lub końcowe mycie i czyszczenie wyrobów, $\mathrm{z}$ równoczesną czasową ich konserwacją.
Proces mycia lub odthuszczania powierzchni jest stosowany w przypadku konieczności usunięcia pozostałości cieczy i olejów obróbkowych, soli hartowniczych, roztworów trawiących, past szlifierskich, drobnych opiłków metalowych oraz innych zanieczyszczeń przed ostatnią fazą technologiczną, jaką jest lakierowanie lub ostateczna konserwacja wyrobu. Zanieczyszczenia i wilgoć pozostające na powierzchni wyrobów po wcześniejszych procesach obróbki powodują powstanie ognisk korozyjnych, dlatego niezbędne jest ich usunięcie przed zabiegami ostatecznej konserwacji. Procesy mycia przebiegają w specjalnych warunkach, w urządzeniach umożliwiających filtrację i dekantację rozpuszczalnika, często w specjalnych komorach wyposażonych w układ mycia oraz w układ płukania umytych części, w specjalnych tunelach do mycia (Baszkiewicz i Kamiński, 2006).

W przypadku gdy na wcześniejszym etapie wyrób metalowy był obrabiany cieczą emulsyjną, zawierającą wodę, zastosowany środek myjąco-konserwujący dodatkowo musi charakteryzować się dobrą zdolnością wypierania wody z powierzchni metalowych, a tym samym ich osuszania. Szybkość korozji wyrobów metalowych wzrasta wraz ze stopniem zawilgocenia powierzchni metalowych. Przyczyną pojawienia się wody na powierzchni wyrobów metalowych jest, oprócz stosowania olejów emulsyjnych, magazynowanie wyrobów w nieogrzewanych magazynach. W rezultacie dobowych wahań temperatury w nieogrzanych magazynach na powierzchni powłok olejowych na zakonserwowanych wyrobach metalowych następuje kondensacja par wody. Woda wydziela się w postaci mikrokropel, które następnie migrują do oleju, tworząc ogniwo korozyjne.

W pierwszym etapie działania środka myjąco-konserwującego następuje zwilżenie powierzchni metalu, wynikające z obniżenia napięcia powierzchniowego na granicy faz środek myjąco-konserwujący-woda, a w konsekwencji na granicy faz środek myjąco-konserwujący-woda-metal. Obniżenie napięcia powierzchniowego powoduje z kolei wzrost zdolności do zwilżania metalu przez środek myjąco-konserwujący. Taki proces ma na celu usunięcie wody/elektrolitu z powierzchni wyrobu metalowego (Zawadzki, 1962, 1969; Surowska, 2002; Zhang et al., 2018).

Efektem silnego zwilżenia powierzchni metalu przez środek myjąco-konserwujący jest usunięcie z niej wody.

Oprócz właściwości myjących i właściwości wypierania wody środek myjąco-konserwujący powinien zagwarantować 
międzyoperacyjną ochronę przed korozją zarówno podczas procesu mycia wyrobów, jak i po jego zakończeniu, do czasu kolejnej operacji, którą najczęściej jest ostateczna konserwacja.

W końcowym etapie działania środka myjąco-konserwującego następuje utworzenie się warstwy adsorpcyjno-chemisorpcyjnej przez inhibitory korozji zawarte w kompozycji środka, zapewniające skuteczną międzyoperacyjną ochronę antykorozyjną. Stosowane środki myjąco-konserwujące nie powinny pozostawiać żadnych osadów i nalotów na mytych lub odttuszczonych częściach wyrobu.

Środki myjąco-konserwujące stosowane są głównie w przemysłach, w których wytwarzane są wyroby metalowe o wysokim stopniu obróbki powierzchni, m.in. w przemyśle precyzyjnym, łożyskowym, narzędzi pomiarowych i w przemyśle motoryzacyjnym. Stosowanie środków myjąco-konserwujących przyczynia się do zmniejszenia ogólnej pracochłonności procesu wytwarzania wyrobów metalowych, umożliwiając łączenie w jedną kilku operacji technologicznych, takich jak osuszanie, mycie i konserwacja (Zawadzki, 1962, 1969; Surowska, 2002; Zhang et al., 2018).

Do międzyoperacyjnego lub końcowego mycia i czyszczenia wyrobów stosowane są najczęściej lekkie frakcje naftowe z udziałem środków powierzchniowo czynnych, takich jak inhibitory korozji, inhibitory utleniania, środki wypierające wodę, inne substancje powierzchniowo-aktywne (TOTAL Polska, 2003; Awad, 2004, Hunter i Paul, 2004; El Ibrahimi et al., 2017; P.134565; P.232455; P.262934; US.3441419; US.5665172; US.5858953; US.5690862).

Oczekuje się, że obecnie stosowane środki nie powinny szkodliwie oddziaływać na zdrowie pracowników, nie powinny zawierać węglowodorów aromatycznych, a w szczególności rakotwórczego benzenu. Odbiorcy oczekują również, aby środek był bezzapachowy, bezbarwny i o wysokiej temperaturze zapłonu. Niestety niektóre obecne na rynku środki charakteryzują się intensywnym zapachem, uciążliwym dla obsługi oraz zbyt niską temperaturą zapłonu, co stwarza duże zagrożenia pożarowe w zakładzie. Dużym mankamentem niektórych dostępnych na rynku środków jest ich zbyt intensywna barwa, uniemożliwiająca ocenę wizualną stopnia starzenia się środka, jak również stopnia jego zanieczyszczenia.

\section{Oleje ochronne}

Podczas produkcji wyrobów metalowych: łożysk, kół zębatych, przyrządów pomiarowych, narzędzi, części do pojazdów, broni, precyzyjnych części maszyn, blach, kształtowników, szyn itp. powstaje problem ich ochrony czasowej przed korozją i rdzewieniem. Czasowa ochrona przed korozją wyprodukowanych wyrobów metalowych polega na ich konserwacji łatwo usuwalnymi lub niewymagającymi usuwania środkami konserwacyjnymi oraz na pakowaniu ochronnym.
Korozja atmosferyczna jest najbardziej odpowiedzialna za proces niszczenia metali, a rodzaj atmosfery i mechanizm procesu pozwala wyróżnić m.in. (Surowska, 2002):

- korozję chemiczną - zachodzi w atmosferze suchej;

- korozję elektrochemiczną - zachodzi w atmosferze wilgotnej. Do czasowej ochrony metali przed korozją stosowane są (Steinmec et al., 1984; Surowska, 2002):

- oleje;

- smary plastyczne;

- suchopowłokowe kompozycje żywiczne i woskowe;

- inhibitory kontaktowe;

- lotne inhibitory korozji.

Pełny proces ochrony czasowej metali obejmuje:

- przygotowanie powierzchni metalu przed nałożeniem środka ochrony czasowej;

- konserwację przez nałożenie powłoki środka ochrony czasowej;

- opakowanie w celu zabezpieczenia przed wpływami atmosferycznymi;

- rozpakowanie oraz dekonserwację powierzchni metalu.

Przed nałożeniem powłoki środka ochrony czasowej powierzchnia metalu musi zostać starannie oczyszczona z wszelkich ciał obcych, wilgoci, zanieczyszczeń mechanicznych, resztek soli, olejów i smarów - od tego zabiegu zależy w znacznym stopniu uzyskany efekt ochronny. Oczyszczanie powierzchni wyrobów odbywa się poprzez oczyszczanie przy użyciu rozpuszczalników, odtłuszczanie w kąpielach alkalicznych lub specjalnych płynach.

Oleje konserwacyjne obok podstawowego składnika takiego jak olej bazowy zawierają dodatki inhibitorów korozji, inhibitorów utlenienia, środków powierzchniowo czynnych wypierających wodę z powierzchni metalu, dodatki przeciwzużyciowe, biocydy, barwniki. Szczególnie ważną rolę odgrywają inhibitory korozji, gdyż czyste oleje i smary węglowodorowe nie wykazują wystarczających właściwości przeciwkorozyjnych. Stosowane w olejach ochronnych inhibitory korozji to najczęściej inhibitory adsorbowane na powierzchni metalu, tworzące szczelną powłokę wypierającą wodę i elektrolity, chroniące $\mathrm{w}$ ten sposób przed procesami elektrochemicznymi (Bart et al., 2013; Hassan et al., 2015; Zhu et al., 2017; P.133639; CA.1258161; CN.102344848; CN.105441167; RU.2184769; US.3383328; US.3897349; US.3981682; US.20160230078).

Oleje konserwacyjne powinny być nakładane na czystą powierzchnię, możliwie szybko po obróbce metalu.

Wytworzona powłoka powinna:

- zapewnić ochronę w środowisku, w którym będą przebywały chronione wyroby, i musi być ona dobrana do stopnia agresywności środowiska;

- wykazywać dobrą przyczepność do powierzchni metalu przy nałożeniu zarówno grubych, jak i cienkich warstw; 
- być nakładana w prosty sposób, odpowiedni do danego wyrobu i warunków konserwacji istniejących u użytkownika;

- dać się łatwo usunąć przez działanie rozpuszczalników lub kąpieli myjących;

- nie może oddziaływać korozyjnie na chroniony metal wskutek wytworzenia się produktów starzenia w czasie długiego magazynowania;

- nie może spływać ani ściekać pod wpływem podwyższonych temperatur, np. przy transporcie w strefie tropikalnej.

W praktyce przemysłowej i eksploatacyjnej oleje konserwacyjne często są klasyfikowane według zapewnianego czasu ochrony metalu przed korozją: do ochrony długookresowej (powyżej 18 miesięcy), średniookresowej (6 do 18 miesięcy), krótkotrwałej (do 6 miesięcy).

\section{Część doświadczalna}

W ramach niniejszej pracy poddano badaniom próbki środka myjąco-konserwującego Pachem-SMK-4917 do mycia wyrobów metalowych oraz do międzyoperacyjnej ochrony przeciwkorozyjnej oraz oleju ochronnego Pachem-OO-4018 do czasowej ochrony (8-15 miesięcy) wyprodukowanych wyrobów metalowych przed korozją.

W tabeli 1 przedstawiono metody badań stosowane do oceny właściwości fizykochemicznych środków myjąco-konserwujących i olejów ochronnych.

Wyniki badań właściwości fizykochemicznych środka myjąco-konserwującego Pachem-SMK-4917 i oleju ochronnego Pachem-OO-4018 zawarto w tabelach 2 i 3.
Tabela 1. Metody badań stosowane do oceny właściwości fizykochemicznych środków myjąco-konserwujących i olejów ochronnych

Table 1. Test methods used to define physicochemical properties of detergents-protective agents and protective oils

\begin{tabular}{|l|c|}
\hline \multicolumn{1}{|c|}{ Nazwa badania } & Norma/metoda \\
\hline \hline Wygląd oleju, $20^{\circ} \mathrm{C}$ & wizualnie \\
\hline Barwa w skali Saybolta & PN-ISO 2049 \\
\hline Zapach & organoleptycznie \\
\hline Gęstość, $20^{\circ} \mathrm{C}$ & ASTM D 4052 \\
\hline Lepkość kinematyczna, $20^{\circ} \mathrm{C} / 40^{\circ} \mathrm{C}$ & PN-EN ISO 3104 \\
\hline Temperatura zapłonu, tygiel otwarty & PN-EN ISO 2592 \\
\hline Liczba zmydlenia & PN-ISO 6293 \\
\hline Liczba kwasowa & PN-ISO 6618 \\
\hline Zawartość wody metodą Karla Fishera & PN-EN ISO 12937 \\
\hline Temperatura płynięcia & PN-ISO 3016 \\
\hline Odczyn wyciągu wodnego & PN-66/C-04064 \\
\hline
\end{tabular}

\section{Środek myjąco-konserwujący Pachem-SMK-4917 do mycia wyrobów metalowych oraz do międzyoperacyjnej ochrony przeciwkorozyjnej}

Środek myjąco-konserwujący Pachem-SMK-4917 zawiera lekkie głębokorafinowane oleje naftowe pozbawione aromatów oraz dodatki uszlachetniające: przeciwkorozyjne, myjące, odwadniające, przeciwutleniające i przeciwpienne.

Jest przeznaczony do stosowania głównie w przemysłach, w których wytwarzane są wyroby metalowe o wysokim stopniu obróbki powierzchni, m.in. w przemyśle precyzyjnym, łożyskowym, narzędzi pomiarowych i w przemyśle motoryzacyjnym.

Tabela 2. Właściwości fizykochemiczne stosowanego do badań środka myjąco-konserwującego Pachem-SMK-4917

Table 2. Physicochemical properties of the Pachem-SMK-4917 cleaning and conservation chemical used for research

\begin{tabular}{|l|c|c|c|}
\hline \multicolumn{1}{|c|}{ Nazwa badania } & $\begin{array}{c}\text { Środek myjąco-konserwujący } \\
\text { Pachem-SMK-4917 }\end{array}$ & Wymagania & Norma/metoda \\
\hline \hline Wygląd oleju, $20^{\circ} \mathrm{C}$ & $\begin{array}{c}\text { klarowna ciecz, barwy } \\
\text { słomkowej }\end{array}$ & $\begin{array}{c}\text { klarowna ciecz, barwy } \\
\text { słomkowej }\end{array}$ & wizualnie \\
\hline Barwa & L 0,5 & L 0,5 & PN-ISO 2049 \\
\hline Zapach & słabo wyczuwalny & słabo wyczuwalny & organoleptycznie \\
\hline Gęstość, $20^{\circ} \mathrm{C}\left[\mathrm{g} / \mathrm{cm}^{3}\right]$ & 0,8205 & $0,80-0,84$ & ASTM D 4052 \\
\hline Lepkość kinematyczna, $20^{\circ} \mathrm{C}\left[\mathrm{mm}^{2} / \mathrm{s}\right]$ & 3,6 & $2,5-5,8$ & PN-EN ISO 3104 \\
\hline Temperatura zapłonu, tygiel otwarty $\left[{ }^{\circ} \mathrm{C}\right]$ & 106,0 & nie niżej niż 100 & PN-EN ISO 2592 \\
\hline Temperatura płynięcia $\left[{ }^{\circ} \mathrm{C}\right]$ & -30 & nie wyżej niż -25 & PN-ISO 3016 \\
\hline Temperatura mętnienia $\left[{ }^{\circ} \mathrm{C}\right]$ & -30 & nie wyżej niż -25 & nie wyżej niż 5,0 \\
\hline Liczba zmydlenia $[\mathrm{mg} \mathrm{KOH} / \mathrm{g}]$ & 1,1 & nie wyżej niż 1,0 & PN-ISO 6293 \\
\hline Liczba kwasowa $[\mathrm{mg} \mathrm{KOH} / \mathrm{g}]$ & 0,9 & nie zawiera & PN-EN ISO 6618 \\
\hline Zawartość wody metodą Karla Fischera $[\%]$ & nie zawiera & obojętny lub zasadowy & PN-66/C-04064 \\
\hline Odczyn wyciągu wodnego & obojętny & & \\
\hline
\end{tabular}


Tabela 3. Właściwości fizykochemiczne stosowanego do badań oleju ochronnego Pachem-OO-4018

Table 3. Physicochemical properties of the protective oil used for testing Pachem-OO-4018

\begin{tabular}{|l|c|c|c|}
\hline \multicolumn{1}{|c|}{ Nazwa badania } & $\begin{array}{c}\text { Olej ochronny } \\
\text { Pachem-OO-4018 }\end{array}$ & Wymagania & Norma/metoda \\
\hline \hline Wygląd oleju, $20^{\circ} \mathrm{C}$ & klarowna ciecz, barwy żółtej & klarowna ciecz, barwy żółtej & wizualnie \\
\hline Gęstość, $20^{\circ} \mathrm{C}\left[\mathrm{g} / \mathrm{cm}^{3}\right]$ & 0,8527 & $0,83-0,87$ & ASTM D 4052 \\
\hline Lepkość kinematyczna w $40^{\circ} \mathrm{C}\left[\mathrm{mm}^{2} / \mathrm{s}\right]$ & 5,02 & $4-6$ & PN-EN ISO 3104 \\
\hline Temperatura zapłonu, tygiel otwarty $\left[{ }^{\circ} \mathrm{C}\right]$ & 120 & nie niżej niż 100 & PN-EN ISO 2592 \\
\hline Temperatura płynięcia $\left[{ }^{\circ} \mathrm{C}\right]$ & -42 & nie wyżej niż -40 & PN-ISO 3016 \\
\hline Liczba zmydlenia $[\mathrm{mg} \mathrm{KOH} / \mathrm{g}]$ & 4,2 & $3-12$ & PN-ISO 6293 \\
\hline Liczba kwasowa $[\mathrm{mg} \mathrm{KOH} / \mathrm{g}]$ & 0,89 & nie wyżej niż 1,0 & PN-ISO 6618 \\
\hline Zawartość wody metodą Karla Fischera $[\%]$ & nie zawiera & nie zawiera & PN-EN ISO 12937 \\
\hline Odczyn wyciągu wodnego & obojętny & obojętny lub zasadowy & PN-66/C-04064 \\
\hline
\end{tabular}

Olej ochronny Pachem-OO-4018 do czasowej ochrony wyprodukowanych wyrobów metalowych przed korozja

Olej ochronny Pachem-OO-4018 zawiera głębokorafinowane oleje naftowe oraz dodatki uszlachetniające przeciwdziałające korozji stali i miedzi, dyspergujące, odwadniające, przeciwutleniające, przeciwpienne.

Olej jest produkowany w kilku klasach lepkościowych: 4-6 $\mathrm{mm}^{2} / \mathrm{s}, 18-22 \mathrm{~mm}^{2} / \mathrm{s}, 40-60 \mathrm{~mm}^{2} / \mathrm{s}$, w temperaturze $40^{\circ} \mathrm{C}$. W niniejszej pracy zaprezentowano wyniki badań oleju ochronnego Pachem-OO-4018 będącego w klasie lepkościowej 4-6 $\mathrm{mm}^{2} / \mathrm{s}$ w temperaturze $40^{\circ} \mathrm{C}$.

Olej ochronny Pachem-OO-4018 jest przeznaczony do średniookresowej ochrony czasowej przed korozją atmosferyczną powierzchni wyrobów metalowych: łożysk tocznych, precyzyjnych przyrządów pomiarowych, narzędzi o dokładnej

Tabela 4. Metody badań stosowane do oceny właściwości funkcjonalnych środków myjącokonserwujących i olejów ochronnych

Table 4. Test methods used to assess the functional properties of cleaning and conservation chemical and protective oils

\begin{tabular}{|l|c|}
\hline \multicolumn{1}{|c|}{ Nazwa badania } & Norma/metoda \\
\hline \hline Oznaczanie grubości powłoki ochronnej na płytce stalowej & $\begin{array}{c}\text { metoda INiG - PIB, na podstawie } \\
\text { PN-70/H-04682, Z.2 }\end{array}$ \\
\hline Napięcie powierzchniowe, $20^{\circ} \mathrm{C}$ & metoda INiG - PIB \\
\hline Punkt anilinowy & PN-ISO 2977 \\
\hline Metoda badania trwałości warstwy ochronnej & metoda INiG - PIB, oparta na \\
NACE 1D182
\end{tabular}

obróbce, maszyn włókienniczych, pomp wtryskowych, małych silników elektrycznych - podczas ich składowania, transportu i użytkowania, w zależności od warunków składowania, od 8 do 15 miesięcy.

Do oceny funkcjonalnych właściwości środka myjąco-konserwującego Pachem-SMK-4917, do mycia wyrobów metalowych oraz do międzyoperacyjnej ochrony przeciwkorozyjnej, a także oleju ochronnego Pachem-OO-4018, do czasowej ochrony wyprodukowanych wyrobów metalowych wytypowano kilka znormalizowanych i nieznormalizowanych, opracowanych w INiG - PIB, metod badań, zgodnie z tabelą 4 .

Wyniki badań właściwości funkcjonalnych środka myjąco-konserwującego Pachem-SMK-4917 i oleju ochronnego Pachem-OO-4018 przedstawiono w tabelach 5 i 6.

\section{Metoda badania trwatości warstwy ochronnej}

Metoda została opracowana w INiG - PIB na podstawie: Wheel Test Method Used for Evaluation of Film-Persistent Corrosion Inhibitors for Oilfield Applications według NACE 1 D 182.

Jest to konwencjonalna metoda badania ubytku masy płytek ze stali, stosowana do oceny wydajności środka, poprzez symulację ciągłego przepływu medium korozyjnego. Do butelek testowych (fot. 1a) wlewano 3-proc. $(\mathrm{m} / \mathrm{m})$ wodny roztwór chlorku sodu $\mathrm{NaCl}$, o $\mathrm{pH}=4,5$, wynikającym z obecności ditlenku węgla $\mathrm{CO}_{2}$. Płytki stalowe Shimstock, o wymiarach $0,13 \times 12,7 \times 76 \mathrm{~mm}$, zanurzano na 1 minutę $\mathrm{w}$ środku 


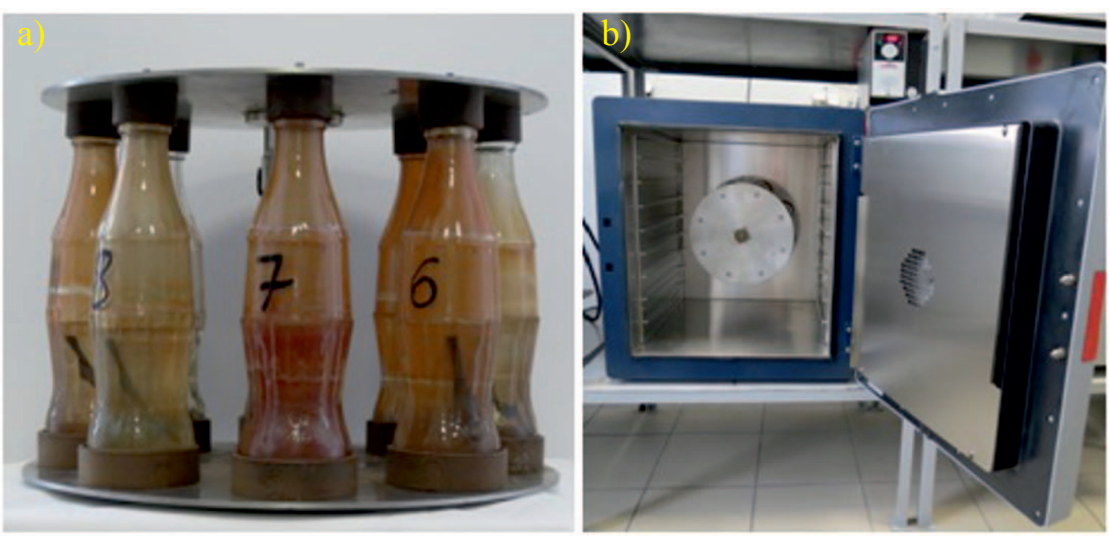

Fot. 1. Badanie trwałości warstwy ochronnej: a) butelki testowe; b) termostat z aparatem obrotowym

Photo 1. Testing the durability of the protective layer: a) test bottles; b) thermostat with a rotating camera

myjąco-konserwującym lub oleju ochronnym, a następnie przenoszono je bezdotykowo do butelek testowych. Do butelek testowych nad powierzchnię cieczy dozowano $\mathrm{CO}_{2}$ i szczelnie je zamykano. Butelki umieszczano w termostacie w temperaturze $65,5^{\circ} \mathrm{C}, \mathrm{w}$ aparacie obrotowym (fot. 1b), który obracał się z prędkością 15 obrotów na minutę. Test prowadzono przez minimum 72 godziny. Po badaniu płytki metalu oczyszczano i oceniano ubytek masy płytki oraz ewentualną obecność korozji wżerowej. Procent ochrony przed korozją obliczano z ubytku masy próbki metalu w obecności inhibitora $W$ (inhib) oraz bez jego udziału $W(0)$.

Procent ochrony, $\% P=W(0)-W($ inhib $) / W(0) \times 100 \%$

\section{Oznaczanie grubości powloki ochronnej na plytce stalowej \\ Metoda została opracowana w INiG - PIB, na podstawie PN-70/H-04682, Załącznik 2.}

Płytki ze stali niskowęglowej, w liczbie minimum trzech, o wymiarach $50 \times 50 \times 3 \mathrm{~mm}$, oczyszczano papierem ściernym, przemywano rozpuszczalnikami, suszono i ważono na wadze analitycznej. Następnie zanurzano w środku myjąco-konserwującym lub oleju ochronnym w temperaturze $20^{\circ} \mathrm{C}$ (klimatyzowane laboratorium) na 3 minuty. Po wyjęciu z naczynia

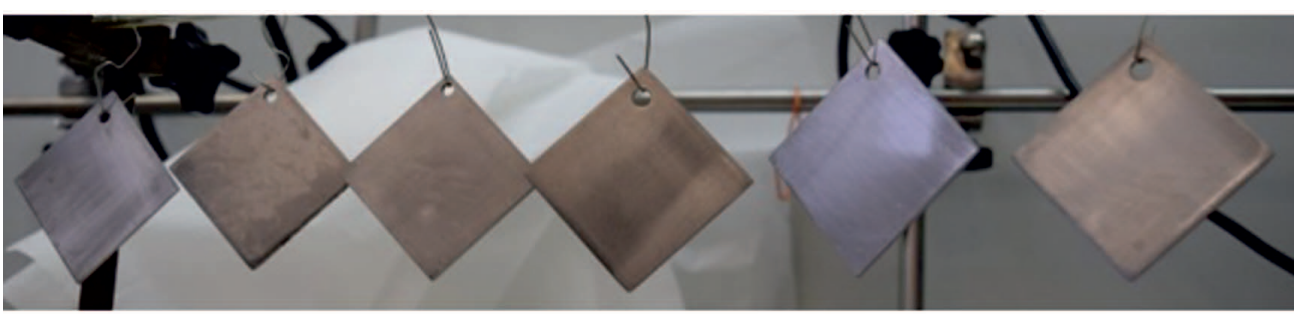

Fot. 2. Wygląd płytek po wyjęciu z testowanego środka/oleju

Photo 2. Appearance of plates after removal from the test agent/oil ze środkiem/olejem zawieszano płytkę testową na 3 godziny w celu ocieknięcia nadmiaru środka/oleju i odparowania rozpuszczalnika (fot. 2). Po zakończeniu badania ponownie ważono płytkę. Masę powłoki ochronnej liczono według wzoru: $m=m_{2}-m_{1}$, gdzie $m_{2}$ jest to masa płytki z powłoką ochronną po odparowaniu rozpuszczalnika, a $m_{1}$ jest to wyjściowa masa płytki. Grubość powłoki ochronnej $[\mu \mathrm{m}]$ obliczano według wzoru: $\mathrm{g}=(\mathrm{m} \times 10000) /$ $(q \times s)$, gdzie: $m$ jest to masa powłoki ochronnej $[\mathrm{g}], q$ - gęstość środka $\left[\mathrm{g} / \mathrm{cm}^{3}\right]$, a $s$ - całkowita powierzchnia płytki testowej $\left[\mathrm{cm}^{2}\right]$.

\section{Wlaściwości deemulgujące}

Standard Guide for Evaluating and Qualifying Oilfield and Refinery Corrosion Inhibitors in the Laboratory, według ASTM G 170-06.

Badanie wykonywano w cylindrze pomiarowym, do którego wlewano środek myjąco-konserwujący i wodę destylowaną w stosunku 50/50\% $(v / v)$ lub olej ochronny i wodę w stosunku 95/5\% (v/v). Każdą próbkę mieszano poprzez 60-krotne odwrócenie do góry dnem, po czym odstawiano. Obserwowano wygląd wydzielających się faz węglowodorowej i wodnej oraz wygląd warstwy międzyfazowej po 2, 3, 5, 30 i 60 minutach oraz po 24 godzinach. Oceniono również czas potrzebny na pełne oddzielenie się obu faz.

\section{Wyniki badań laboratoryjnych środka myjąco-konserwującego Pachem-SMK-4917}

Wykonano badania grubości powłoki ochronnej na płytce stalowej, oznaczono napięcie powierzchniowe w $20^{\circ} \mathrm{C}$ oraz wysokość punktu anilinowego dla środka myjąco-konserwującego Pachem-SMK-4917, a wyniki badań przedstawiono w tabeli 5 .

Przeprowadzono dynamiczne badanie trwałości warstwy ochronnej środka myjąco-konserwującego PachemSMK-4917 w porównaniu do środka komercyjnego A, według NACE 1D182. Badania wykonano w 3-proc. $(\mathrm{m} / \mathrm{m})$ wodnym roztworze chlorku sodu, po wcześniejszym barbotażu tego roztworu ditlenkiem węgla, do $\mathrm{pH} 4,5$, w temperaturze $65^{\circ} \mathrm{C}$, w czasie 72 godzin, na płytkach stalowych uprzednio zanurzonych w badanym środku. Wyniki badań korozyjnych przedstawiono w tabelach 5 i 6 . 
Wykonano statyczne badanie działania korodującego na płytkach ze stali $\left(80^{\circ} \mathrm{C}\right)$ i na płytkach z miedzi $\left(50^{\circ} \mathrm{C}\right)$, a wyniki przedstawiono w tabelach 5,7 i 8 .

Przeprowadzono statyczne badanie właściwości przeciwkorozyjnych w wilgotnej atmosferze, w temperaturze $49^{\circ} \mathrm{C}$, na płytkach ze stali, a wyniki badań przedstawiono w tabelach 5 i 9 .

Wykonano badanie właściwości deemulgujących środka myjąco-konserwującego Pachem-SMK-4917 - wyniki badań przedstawiono w tabelach 5 i 10.

Tabela 5. Wyniki badań właściwości funkcjonalnych środka myjąco-konserwującego PACHEM-SMK-4917

Table 5. Results of functional properties tests for PACHEM-SMK-4917 cleaning and conservation chemical

\begin{tabular}{|c|c|c|c|c|c|}
\hline \multicolumn{2}{|c|}{ Nazwa badania } & Jednostka & $\begin{array}{l}\text { PACHEM- } \\
\text { SMK-4917 }\end{array}$ & Wymagania & Norma/metoda \\
\hline \multicolumn{2}{|c|}{$\begin{array}{l}\text { Oznaczanie grubości powłoki ochronnej na płytce } \\
\text { stalowej }\end{array}$} & $\mu \mathrm{m}$ & 0,5 & $0,2-2,0$ & $\begin{array}{c}\text { metoda } \mathrm{INiG}-\mathrm{PIB}, \\
\text { na podstawie } \\
\text { PN-70/H-04682, } \\
\text { Załącznik 2 }\end{array}$ \\
\hline \multicolumn{2}{|l|}{ Napięcie powierzchniowe, $20^{\circ} \mathrm{C}$} & $\mathrm{mN} / \mathrm{m}$ & 27,0 & nie wyżej niż 30,0 & metoda INiG - PIB \\
\hline \multicolumn{2}{|l|}{ Punkt anilinowy } & ${ }^{\circ} \mathrm{C}$ & 71,5 & nie wyżej niż 80,0 & PN-ISO 2977 \\
\hline \multirow{2}{*}{$\begin{array}{l}\text { Metoda badania trwałości war- } \\
\text { stwy ochronnej }\end{array}$} & $\begin{array}{l}\text { ochrona przed } \\
\text { korozją }\end{array}$ & $\%$ & 98,2 & nie niżej niż 97,0 & \multirow{2}{*}{$\begin{array}{c}\text { metoda INiG - PIB, } \\
\text { oparta na NACE } \\
\text { 1D182 }\end{array}$} \\
\hline & szybkość korozji & $\mathrm{mm} / \mathrm{rok}$ & 0,02 & nie wyżej niż 0,03 & \\
\hline $\begin{array}{l}\text { Działanie korodujące na stali w } \\
\text { temp. } 80^{\circ} \mathrm{C} \text { w czasie } 96 \text { godzin }\end{array}$ & \multirow{2}{*}{$\begin{array}{l}\text { wygląd płytek po } \\
\text { badaniu w porów- } \\
\text { naniu ze wzorcem }\end{array}$} & $\begin{array}{l}\text { stopień pociemnienia/ } \\
\text { ogniska korozji }\end{array}$ & $\begin{array}{l}\text { brak pociemnienia } \\
\text { i ognisk korozji }\end{array}$ & $\begin{array}{l}\text { brak pociemnienia } \\
\text { i ognisk korozji }\end{array}$ & PN-C-04093 \\
\hline $\begin{array}{l}\text { Działanie korodujące na mie- } \\
\text { dzi w temp. } 50^{\circ} \mathrm{C} \text { w czasie } \\
96 \text { godzin }\end{array}$ & & stopień pociemnienia & $1 \mathrm{a}$ & nie wyżej niż 1 a & PN-C-04093 \\
\hline $\begin{array}{l}\text { Właściwości przeciwkorozyjne } \\
\text { w wilgotnej atmosferze }(100 \%) \\
\text { na płytkach ze stali, } 49^{\circ} \mathrm{C}\end{array}$ & $\begin{array}{l}\text { czas, po jakim po- } \\
\text { jawiły się pierw- } \\
\text { sze oznaki korozji }\end{array}$ & godzina & po 336 & nie mniej niż po 24 & ASTM D 1748-02 \\
\hline Właściwości deemulgujące & $\begin{array}{l}\text { czas pełnego roz- } \\
\text { działu na } 2 \text { fazy }\end{array}$ & minuta & 30 & nie wyżej niż 24 h & ASTM G 170-06 \\
\hline
\end{tabular}

Tabela 6. Wyniki badań korozyjnych środka myjąco-konserwującego Pachem-SMK-4917 w porównaniu do środka komercyjnego A według NACE 1D182

Table 6. Corrosion test results of Pachem-SMK-4917 dcleaning and conservation chemical, compared to commercial agent A, according to NACE 1D182

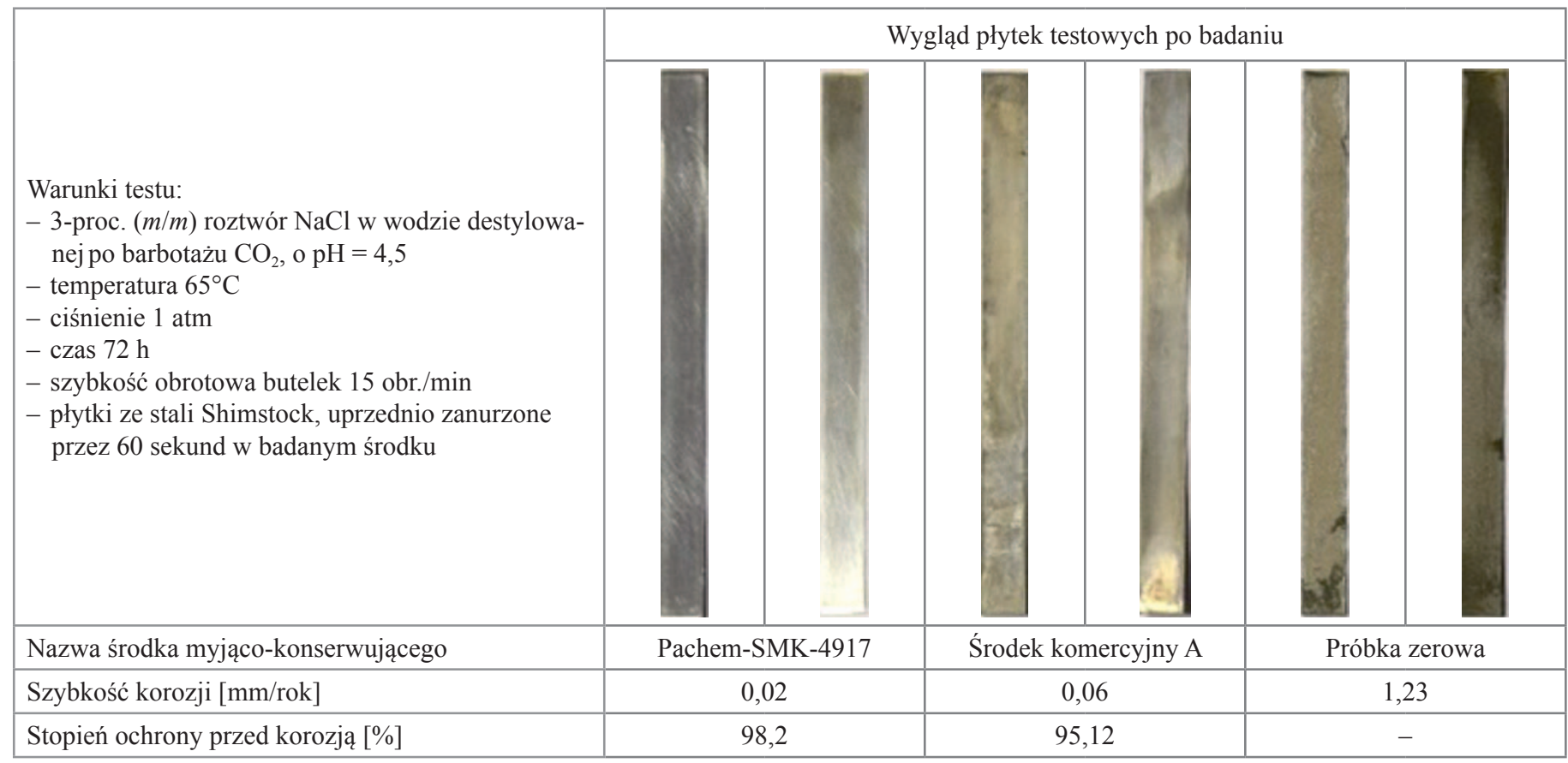


Tabela 7. Wyniki badań korozyjnych środka myjąco-konserwującego Pachem-SMK-4917 w porównaniu do środka komercyjnego A według PN-C-04093

Table 7. Corrosion test results of Pachem-SMK-4917 cleaning and conservation chemical, compared to commercial agent A, according to PN-C-04093 standard

\begin{tabular}{|c|c|c|}
\hline \multirow{3}{*}{$\begin{array}{l}\text { Warunki testu: } \\
\text { - temperatura } 80^{\circ} \mathrm{C} \\
\text { - ciśnienie } 1 \mathrm{~atm} \\
\text { - czas } 96 \mathrm{~h} \\
\text { - płytki ze stali zgodne z normą, } \\
\text { zanurzone w badanym środku }\end{array}$} & \multicolumn{2}{|c|}{ Wygląd płytek testowych po badaniu } \\
\hline & & \\
\hline & Pachem-SMK-4917 & Środek komercyjny A \\
\hline Wygląd płytek po badaniu & $\begin{array}{c}\text { brak pociemnienia i oznak korozji } \\
\text { na płytkach testowych }\end{array}$ & pociemnienie płytek testowych \\
\hline
\end{tabular}

Tabela 8. Wyniki badań korozyjnych środka myjąco-konserwującego Pachem-SMK-4917 w porównaniu do środka komercyjnego A według PN-C-04093

Table 8. Corrosion test results of Pachem-SMK-4917 cleaning and conservation chemical, compared to commercial agent A, according to PN-C-04093 standard

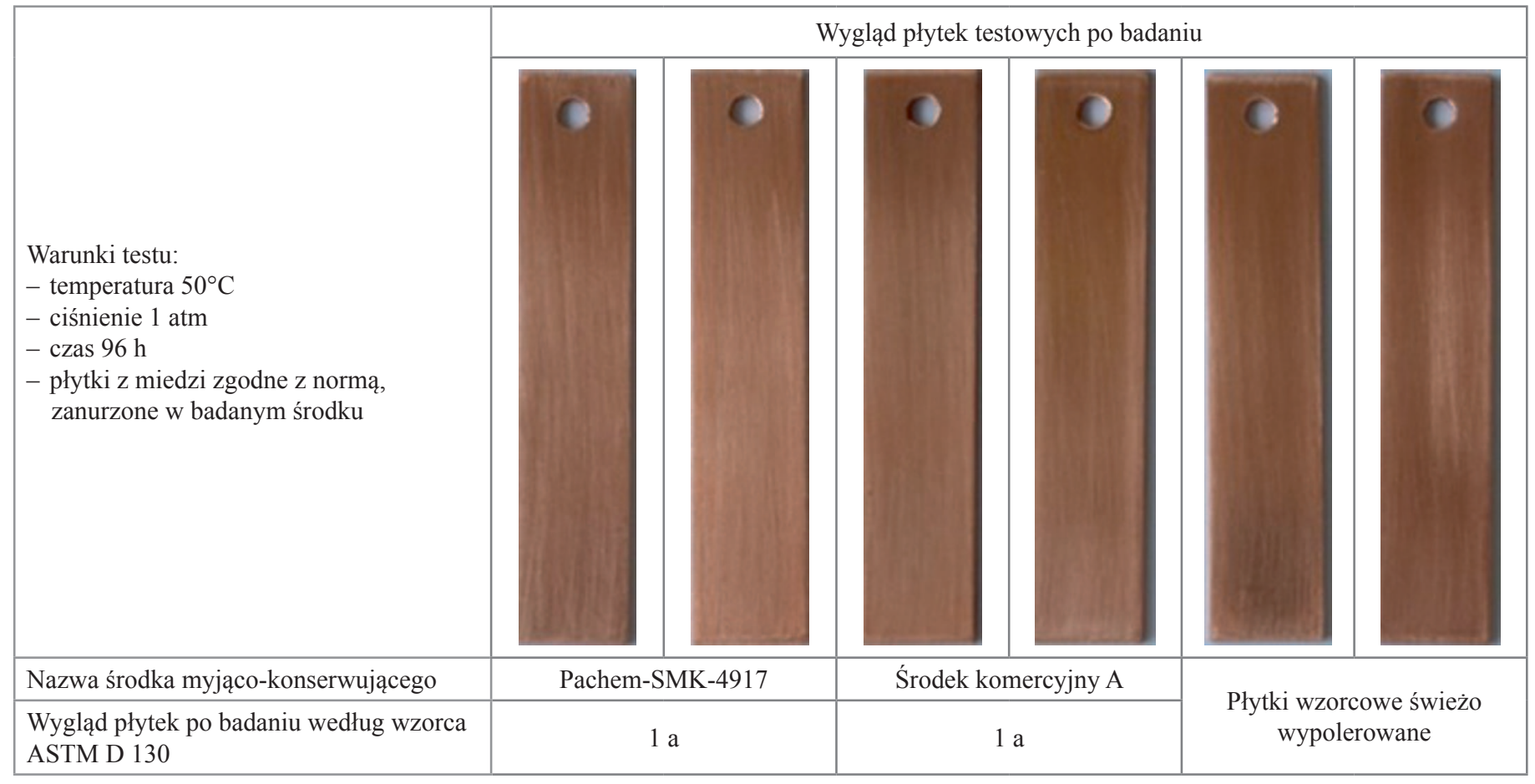




\section{NAFTA-GAZ}

Tabela 9. Wyniki badań przeciwkorozyjnych w komorze wilgotnościowej dla środka myjąco-konserwującego Pachem-SMK-4917 w porównaniu do środka komercyjnego A według ASTM D 1748-02

Table 9. Anticorrosion test results in a humidity chamber for Pachem-SMK-4917 cleaning and conservation chemical, compared to commercial A, according to ASTM D 1748-02

Warunki testu:

- wilgotność $100 \%$

- temperatura $49^{\circ} \mathrm{C}$

- ciśnienie $1 \mathrm{~atm}$

- płytki ze stali, zgodne z normą, uprzednio zanurzone przez 90 sekund w badanym środku i wysuszone w czasie 2 godzin w temperaturze $20^{\circ} \mathrm{C}$

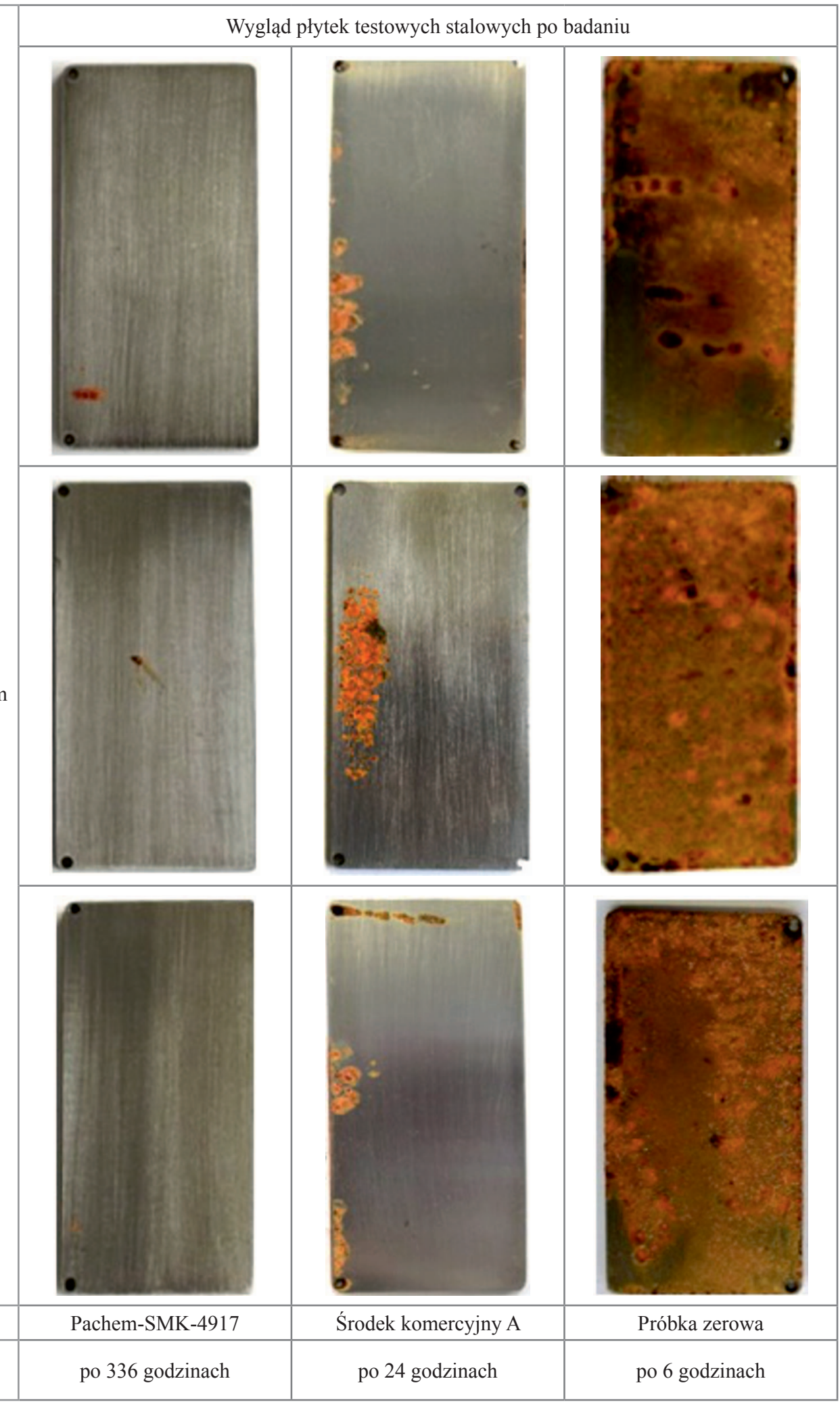


Tabela 10. Wyniki badań właściwości deemulgujących środka myjąco-konserwującego Pachem-SMK-4917 w porównaniu do środka komercyjnego A według ASTM G 170-06

Table 10. Results of testing of demulsifying properties for Pachem-SMK-4917 cleaning and conservation chemical, compared to commercial A, according to ASTM G 170-06

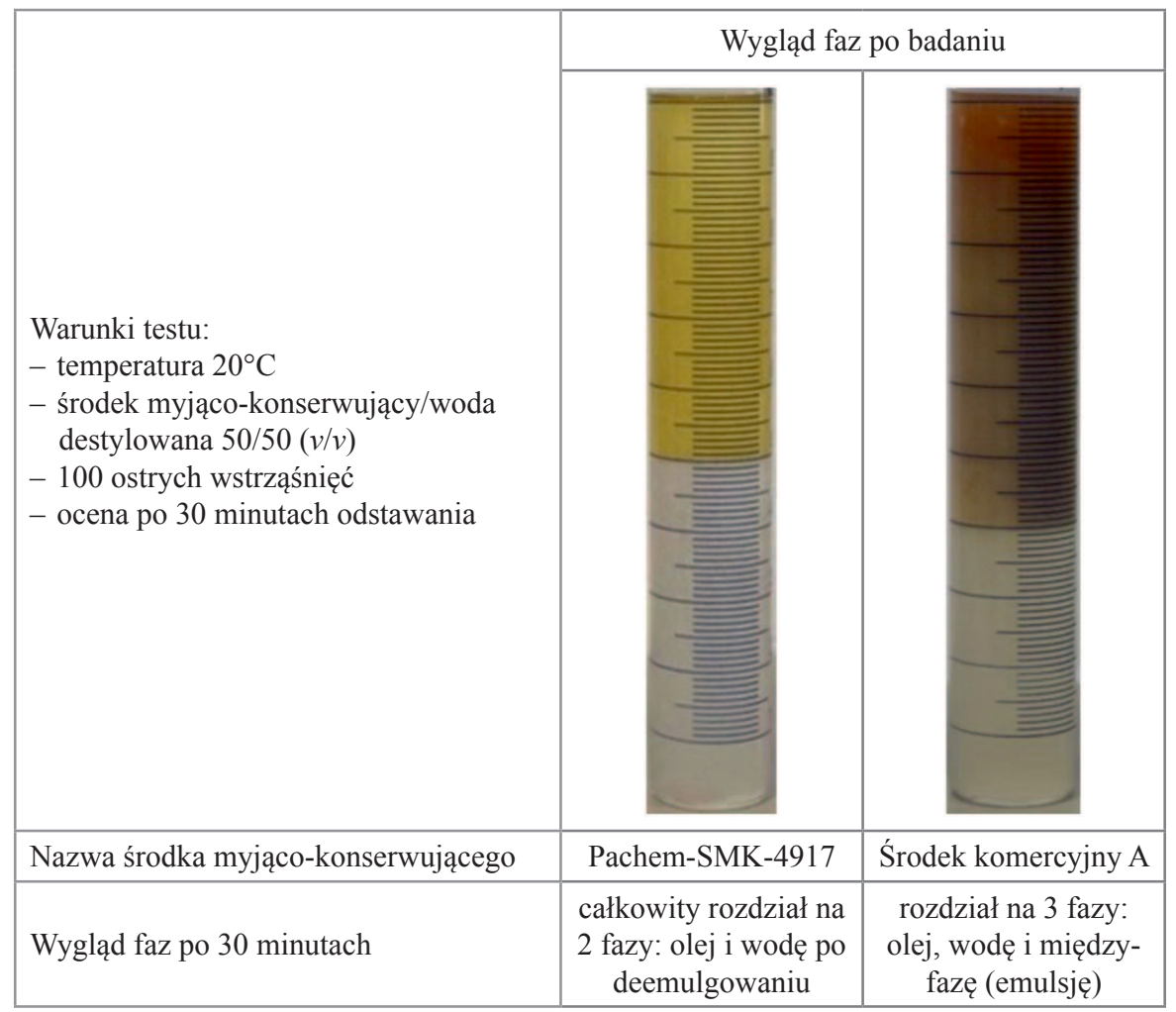

w temperaturze $20^{\circ} \mathrm{C}$ oraz właściwości przeciwkorozyjnych metodą statyczną kroplową w temperaturze $60^{\circ} \mathrm{C}$, dla oleju ochronnego Pachem-OO-4018. Wyniki badań przedstawiono w tablicy 11 .

Przeprowadzono dynamiczne badania trwałości warstwy ochronnej, wytworzonej przez olej ochronny Pachem-OO-4018, w porównaniu do oleju komercyjnego B, według NACE 1D182. Badania wykonano w 3-proc. $(\mathrm{m} / \mathrm{m})$ roztworze chlorku sodu w wodzie po wcześniejszym barbotażu tego roztworu ditlenkiem węgla, do $\mathrm{pH} 4,5$, w temperaturze $65^{\circ} \mathrm{C}$, w czasie 72 godzin, na płytkach stalowych uprzednio zanurzonych w badanym środku. Wyniki badań korozyjnych przedstawiono w tabelach 11 i 12 .

Wykonano badania właściwości przeciwkorozyjnych w wilgotnej atmosferze $(100 \%)$, w temperaturze $49^{\circ} \mathrm{C}$, oleju ochronnego Pachem-OO-4018 w porównaniu do oleju komercyjnego $\mathrm{B}$, a wyniki zawarto w tabelach 11 i 13.

Przeprowadzono badania właściwości ochronnych przed działaniem jonów chlor-

\section{Wyniki badań laboratoryjnych oleju ochronnego Pachem-00-4018}

Przeprowadzono badania: grubości powłoki ochronnej na płytce stalowej, właściwości przeciwkorozyjnych na trzpieniu stalowym przy zastosowaniu roztworu soli nieorganicznych kowych $\mathrm{Cl}^{-}$metodą emulsyjną na płytkach ze stali, miedzi, $\mathrm{z}$ brązu cynowo-cynkowo-ołowianego, z brązu aluminiowego, a wyniki przedstawiono w tabelach 11 i 14 .

Wykonano badanie właściwości deemulgujących oleju ochronnego Pachem-OO-4018 w porównaniu do oleju komercyjnego B, a wyniki badań zamieszczono w tabelach 11 i 15.

Tabela 11. Właściwości funkcjonalne stosowanego do badań oleju ochronnego Pachem-OO-4018

Table 11. Functional properties of Pachem-OO-4018 protective oil used for research

\begin{tabular}{|c|c|c|c|c|c|}
\hline \multicolumn{2}{|c|}{ Nazwa badania } & Jednostka & $\begin{array}{c}\text { Olej ochronny } \\
\text { Pachem-OO-4018 }\end{array}$ & Wymagania & $\begin{array}{l}\text { Normy/ } \\
\text { procedury }\end{array}$ \\
\hline \multicolumn{2}{|c|}{$\begin{array}{l}\text { Oznaczanie grubości powłoki ochronnej na płyt- } \\
\text { ce stalowej }\end{array}$} & $\mu \mathrm{m}$ & $0,5-4,0$ & $\begin{array}{c}\text { podawać } \\
\text { w atestach }\end{array}$ & $\begin{array}{c}\text { Metoda INiG - PIB, } \\
\text { na podstawie } \\
\text { PN-70/H-04682, Zał. } 2\end{array}$ \\
\hline $\begin{array}{l}\text { Właściwości przeciwkorozyjne } \\
\text { na trzpieniu stalowym przy za- } \\
\text { stosowaniu roztworu soli nie- } \\
\text { organicznych, } 20^{\circ} \mathrm{C}\end{array}$ & \multirow{2}{*}{$\begin{array}{l}\text { wygląd płytek po } \\
\text { badaniu w porów- } \\
\text { naniu ze wzorcem }\end{array}$} & \multirow{2}{*}{$\begin{array}{l}\text { stopień pociem- } \\
\text { nienia/ ogniska } \\
\text { korozji }\end{array}$} & $\begin{array}{l}\text { brak pociemnienia } \\
\text { i ognisk korozji }\end{array}$ & $\begin{array}{l}\text { brak pociemnienia } \\
\text { i ognisk korozji }\end{array}$ & PN-ISO-7120 \\
\hline $\begin{array}{l}\text { Właściwości przeciwkorozyj- } \\
\text { ne metodą statyczną kroplową, } \\
\text { stal, w } 60^{\circ} \mathrm{C}, 24 \mathrm{~h}\end{array}$ & & & $\begin{array}{l}\text { brak pociemnienia } \\
\text { i ognisk korozji }\end{array}$ & $\begin{array}{l}\text { brak pociemnienia } \\
\text { i ognisk korozji }\end{array}$ & BN-73/0535-33 \\
\hline \multirow{2}{*}{$\begin{array}{l}\text { Metoda badania trwałości war- } \\
\text { stwy ochronnej }\end{array}$} & $\begin{array}{l}\text { ochrona przed } \\
\text { korozją }\end{array}$ & $\%$ & 98,8 & nie niżej niż 98,0 & \multirow{2}{*}{$\begin{array}{l}\text { metoda INiG - PIB, } \\
\text { oparta na podstawie } \\
\text { NACE 1D182 }\end{array}$} \\
\hline & szybkość korozji & $\mathrm{mm} /$ rok & 0,015 & nie wyżej niż 0,025 & \\
\hline $\begin{array}{l}\text { Właściwości przeciwkorozyj- } \\
\text { ne w wilgotnej atmosferze na } \\
\text { płytkach ze stali, } 49^{\circ} \mathrm{C}\end{array}$ & $\begin{array}{l}\text { czas, po którym } \\
\text { pojawiły się pierw- } \\
\text { sze oznaki korozji }\end{array}$ & godzin & 768 & nie niżej niż 360 & ASTM D 1748-02 \\
\hline
\end{tabular}


cd. Tabela 11/ ect. Table 11

\begin{tabular}{|c|c|c|c|c|c|}
\hline \multicolumn{2}{|c|}{ Nazwa badania } & Jednostka & $\begin{array}{c}\text { Olej ochronny } \\
\text { Pachem-OO-4018 }\end{array}$ & Wymagania & Normy/ \\
\hline \multicolumn{5}{|l|}{$\begin{array}{l}\text { Właściwości ochronne przed } \\
\text { działaniem } \mathrm{Cl}^{-} \text {metodą emul- } \\
\text { syjną w } 50^{\circ} \mathrm{C}\end{array}$} & \multirow{5}{*}{ PN-66/C-04059 } \\
\hline - płytki ze stali & \multirow{4}{*}{$\begin{array}{l}\text { wygląd płytek po } \\
\text { badaniu w porów- } \\
\text { naniu ze wzorcem }\end{array}$} & \multirow{4}{*}{$\begin{array}{l}\text { stopień pociem- } \\
\text { nienia/ ogniska } \\
\text { korozji }\end{array}$} & $\begin{array}{l}\text { brak pociemnienia } \\
\text { i ognisk korozji }\end{array}$ & $\begin{array}{l}\text { brak pociemnienia } \\
\text { i ognisk korozji }\end{array}$ & \\
\hline - płytki z miedzi & & & $\begin{array}{l}\text { brak pociemnienia } \\
\text { i ognisk korozji }\end{array}$ & $\begin{array}{l}\text { brak pociemnienia } \\
\text { i ognisk korozji }\end{array}$ & \\
\hline $\begin{array}{l}\text { - płytki z brązu cynowo-cyn- } \\
\text { kowo-ołowianego }\end{array}$ & & & $\begin{array}{l}\text { brak pociemnienia } \\
\text { i ognisk korozji }\end{array}$ & $\begin{array}{l}\text { brak pociemnienia } \\
\text { i ognisk korozji }\end{array}$ & \\
\hline - płytki z brązu aluminiowego & & & $\begin{array}{l}\text { brak pociemnienia } \\
\text { i ognisk korozji }\end{array}$ & $\begin{array}{l}\text { brak pociemnienia } \\
\text { i ognisk korozji }\end{array}$ & \\
\hline Właściwości deemulgujące & $\begin{array}{l}\text { czas pełnego roz- } \\
\text { działu na } 2 \text { fazy }\end{array}$ & minuta & 15 & nie wyżej niż 30 & ASTM G 170-06 \\
\hline
\end{tabular}

Tabela 12. Wyniki badań korozyjnych oleju ochronnego Pachem-OO-4018 w porównaniu do oleju komercyjnego B według NACE 1D182

Table 12. Corrosion tests results of the Pachem-OO-4018 protective oil compared to commercial oil B, according to NACE 1 D182

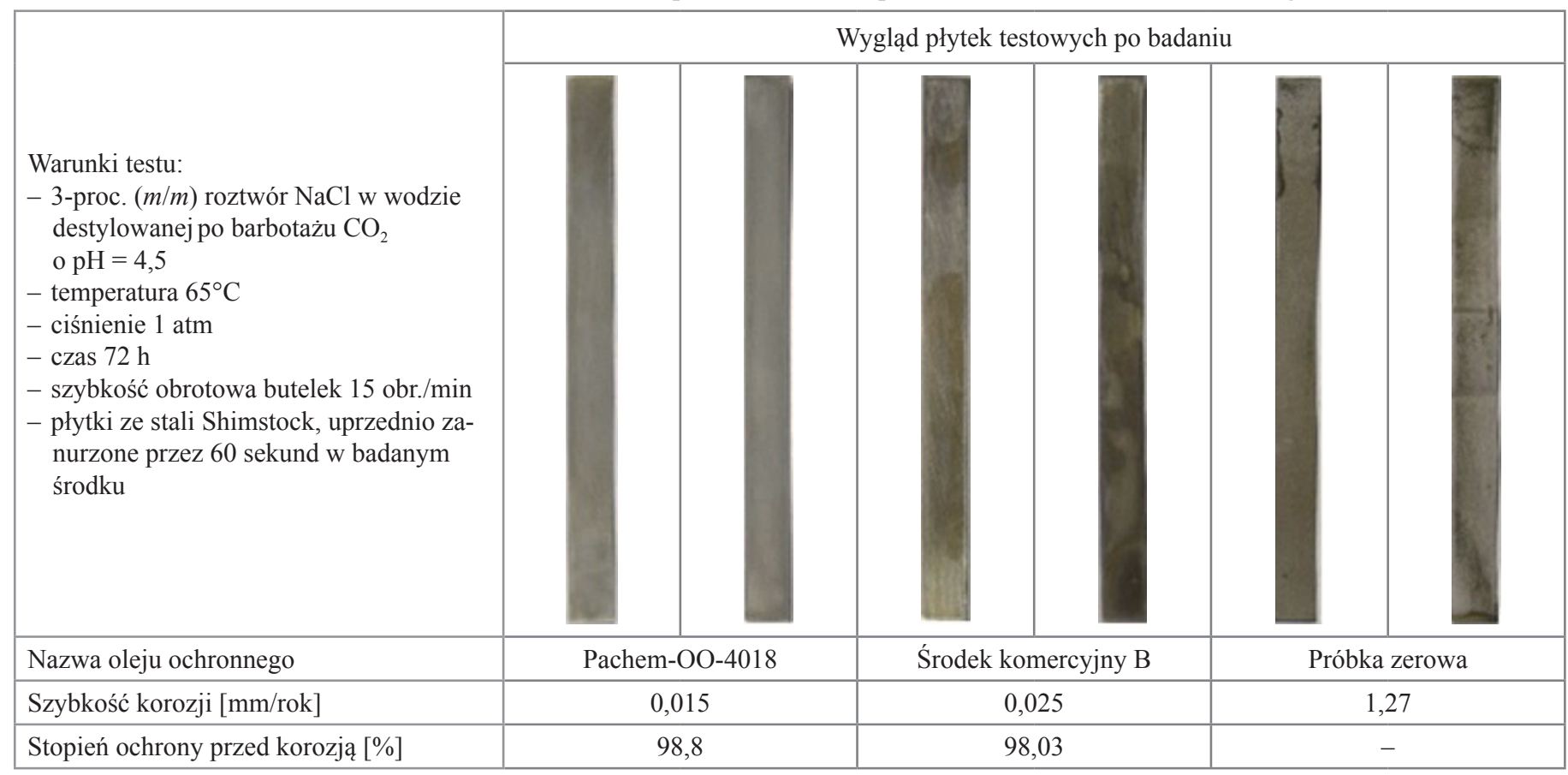

\section{Podsumowanie i wnioski}

\section{Środek myjąco-konserwujący Pachem-SMK-4917}

Przeprowadzono badania laboratoryjne właściwości fizykochemicznych i funkcjonalnych innowacyjnego produktu środka myjąco-konserwującego Pachem-SMK-4917, opracowanego w Instytucie Nafty i Gazu - Państwowym Instytucie Badawczym, we współpracy z firmą Pachemtech, w ramach projektu Innowacyjne środki chemiczne z udziatem zmodyfikowanej imidazoliny dla przemystu rafineryjnego, wydobywczego ropy naftowej, hutniczego i maszynowego.

Badania wykazały, że środek myjąco-konserwujący PachemSMK-4917 jest bezzapachową cieczą o jasnej barwie, tworzy na płytce stalowej cienką powłokę ochronną o grubości około 0,5 mikrometra, jego napięcie powierzchniowe $\mathrm{w} 20^{\circ} \mathrm{C}$ jest na poziomie $27 \mathrm{mN} / \mathrm{m}$, a wysokość punktu anilinowego wynosi $71,5^{\circ} \mathrm{C}$. Niskie napięcie powierzchniowe i niski punkt anilinowy świadczą o dobrych właściwościach myjących produktu. Środki myjąco-konserwujące dostępne na rynku charakteryzują się na ogół znacznie wyższym, zbliżonym do $80^{\circ} \mathrm{C}$, punktem anilinowym oraz wyższym, zbliżonym do $30 \mathrm{mN} / \mathrm{m}$, napięciem powierzchniowym.

Przeprowadzono dynamiczne badanie trwałości warstwy ochronnej środka myjąco-konserwującego Pachem-SMK-4917 w porównaniu do środka komercyjnego A, według NACE 1D182. Badania wykazały, że szybkość korozji testowych płytek Steel 
Tabela 13. Wyniki badań korozyjnych w komorze wilgotnościowej oleju ochronnego Pachem-OO-4018 w porównaniu do oleju komercyjnego B według ASTM D 1748-02

Table 13. Corrosion test results in a humidity chamber for Pachem-OO-4018 protective oil, compared to commercial oil B, according to ASTM D 1748-02

Warunki testu:

- wilgotność $100 \%$

- temperatura $49^{\circ} \mathrm{C}$

- ciśnienie $1 \mathrm{~atm}$

- płytki ze stali, zgodne z normą, uprzednio zanurzone przez 90 sekund w badanym środku i wysuszone w czasie 2 godzin w temperaturze $20^{\circ} \mathrm{C}$

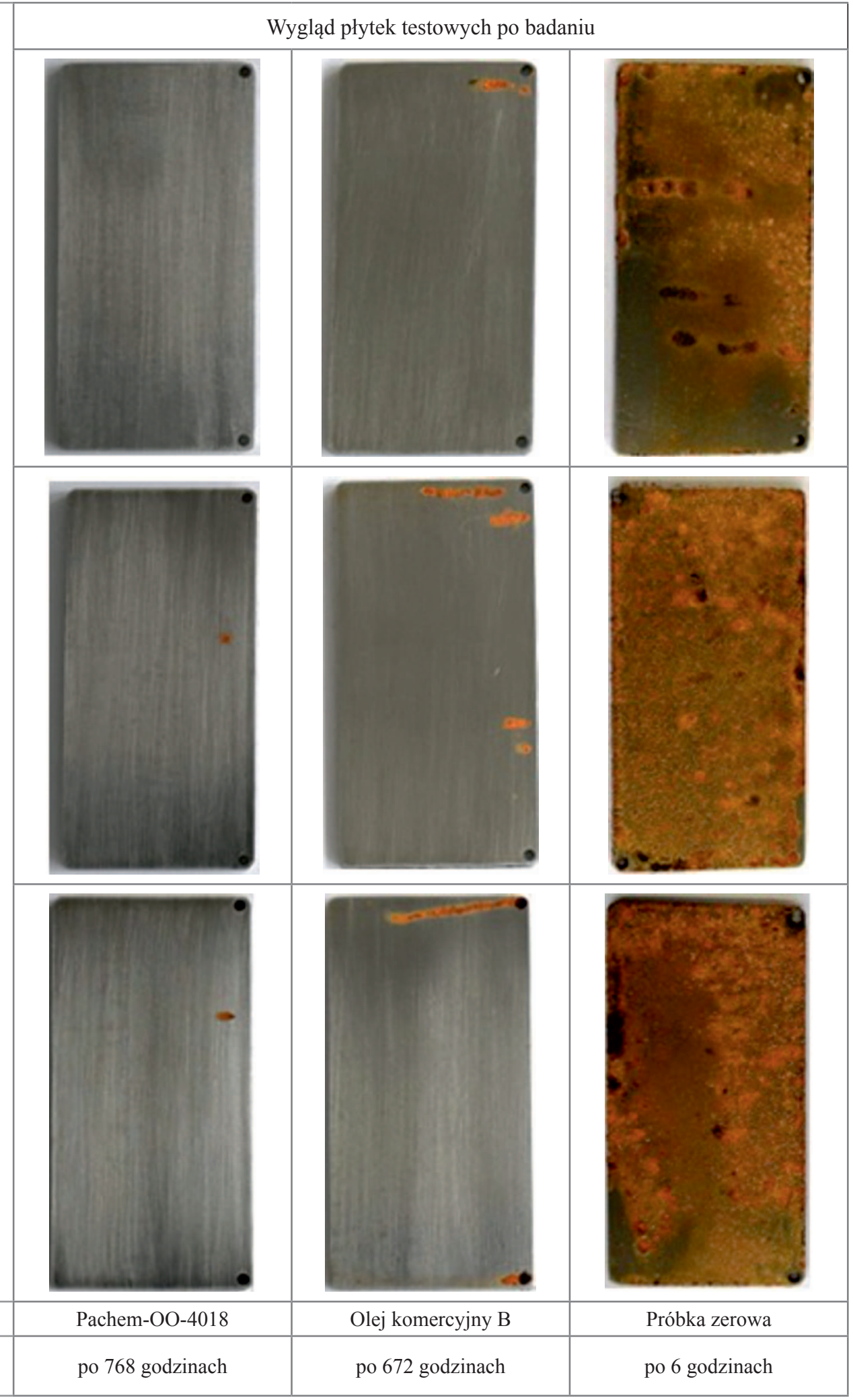


Tabela 14. Wyniki badań korozyjnych oleju ochronnego Pachem-OO-4018 metodą emulsyjną - działanie jonów chlorkowych, według PN-66/C-04059

Table 14. Corrosion tests results of the protective oil Pachem-OO-4018 using the emulsion method - the action of chloride ions, according to PN-66/C-04059

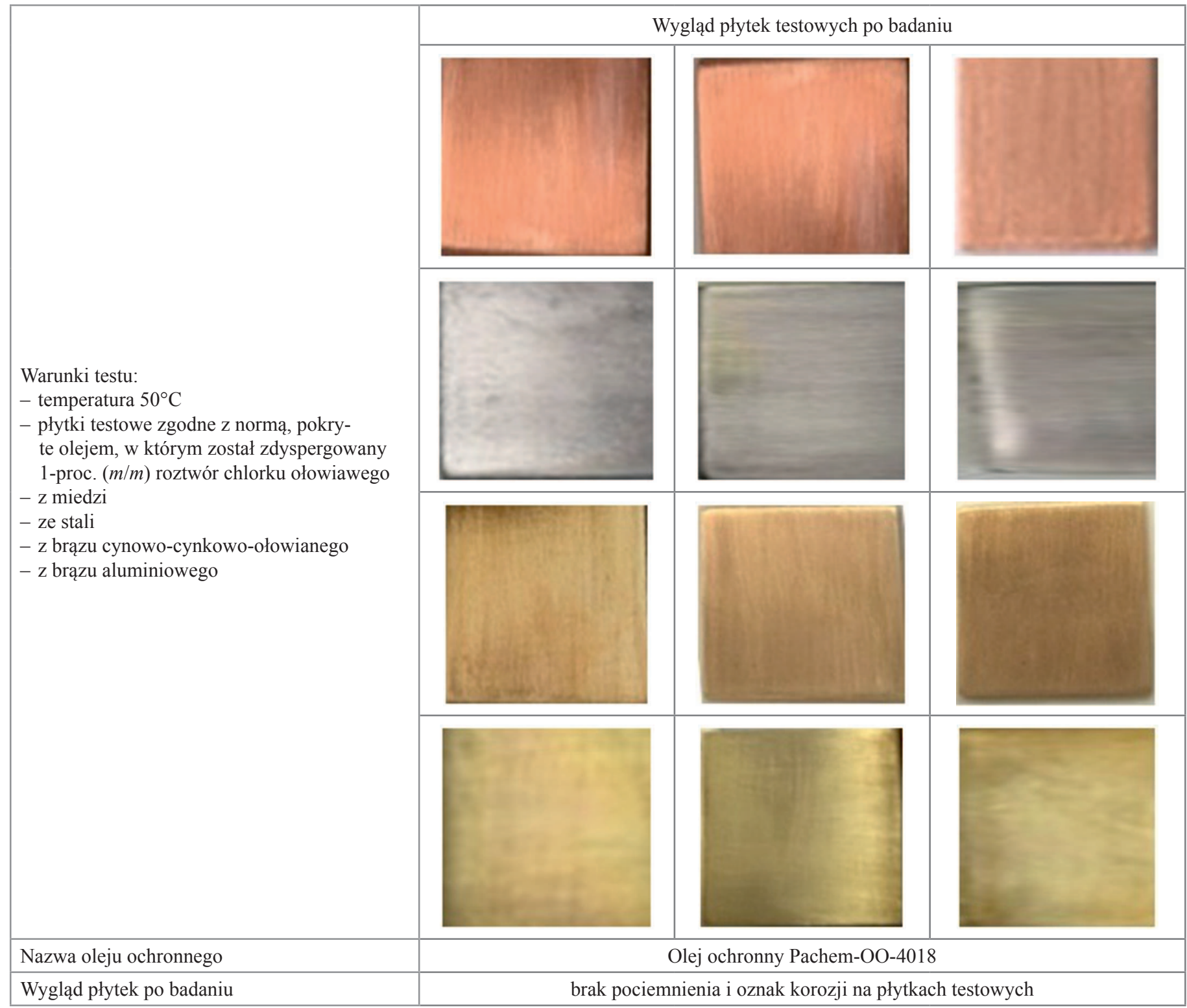

Shimstock pokrytych środkiem myjąco-konserwującym PachemSMK-4917 wynosiła 0,02 mm/rok, a stopień ochrony przed korozją kształtował się na poziomie 98,2\%. W przypadku środka komercyjnego A szybkość korozji testowych płytek Steel Shimstock wynosiła $0,06 \mathrm{~mm} / \mathrm{rok}$, a stopień ochrony przed korozją był na poziomie $95,12 \%$.

Wykonano badanie działania korodującego środka myjącokonserwującego Pachem-SMK-4917, na płytki ze stali w temperaturze $80^{\circ} \mathrm{C}$, w porównaniu do środka komercyjnego A. Badania te wykazały, że w przypadku środka Pachem-SMK-4917 brak jest pociemnienia płytek ze stali, zaś w przypadku środka komercyjnego A zaobserwowano pociemnienie płytek.

Wykonano badanie działania korodującego środka myjąco-konserwującego Pachem-SMK-4917 na płytki z miedzi w temperaturze $50^{\circ} \mathrm{C}$. Po zakończeniu badań stwierdzono, że zarówno w przypadku środka Pachem-SMK-4917, jak i środka komercyjnego A barwa płytek z miedzi nie zmieniła się w stosunku do płytek z miedzi świeżo wypolerowanych.

Przeprowadzono badania właściwości przeciwkorozyjnych w wilgotnej atmosferze, w temperaturze $49^{\circ} \mathrm{C}$, na płytkach ze stali. Badania te wykazały, że w przypadku środka myjąco-konserwującego Pachem-SMK-4917 pierwsze oznaki korozji pojawiły się po 336 godzinach, dla środka komercyjnego A po 24 godzinach, a dla próbki zerowej po 6 godzinach.

Wykonane badania właściwości deemulgujących wykazały, że w przypadku środka Pachem-SMK-4917 proces deemulgowania przebiega szybko, do 30 minut następuje całkowite rozdzielenie substancji od wody. W przypadku środka 
Tablica 15. Skłonność do emulgowania oleju ochronnego Pachem-OO-4018 w porównaniu do oleju komercyjnego B, wg ASTM G 170-06

Table 15. Emulsification tendency of Pachem-OO-4018 protective oil compared to commercial oil B, according to ASTM G 170-06

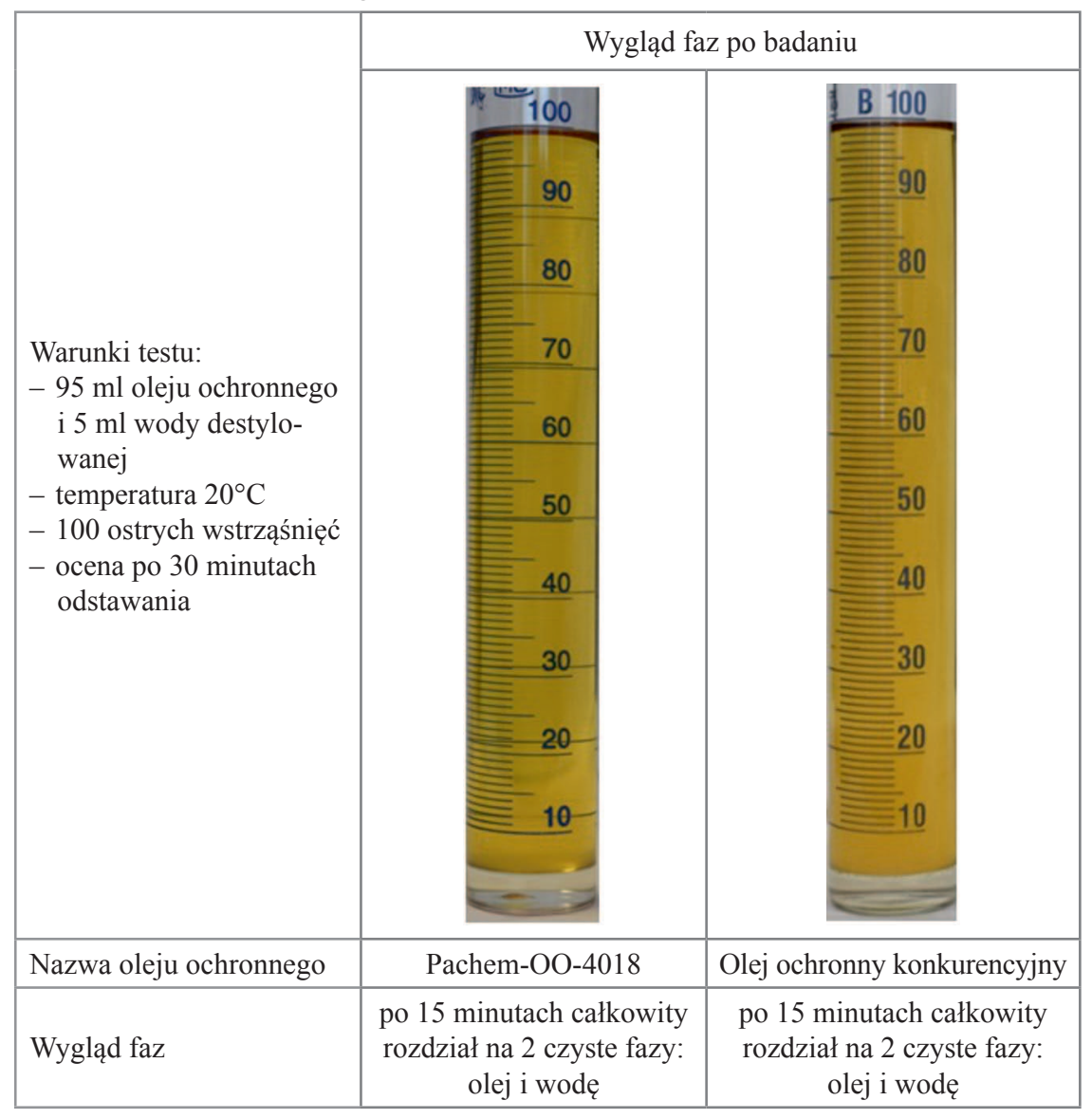

Wykonano badanie właściwości przeciwkorozyjnych oleju ochronnego Pachem-OO-4018 na trzpieniu stalowym przy zastosowaniu roztworu soli nieorganicznych w temperaturze $20^{\circ} \mathrm{C}$ oraz metodą statyczną kroplową w temperaturze $60^{\circ} \mathrm{C}$. W obydwu badaniach stwierdzono brak korozji na stalowych powierzchniach.

Przeprowadzono dynamiczne badania trwałości warstwy ochronnej wytworzonej przez olej ochronny Pachem-OO-4018 w porównaniu do oleju komercyjnego $\mathrm{B}$, według NACE 1D182. Badania wykazały, że szybkość korozji testowych płytek Steel Shimstock pokrytych olejem ochronnym Pachem-OO-4018 wynosiła $0,015 \mathrm{~mm} / \mathrm{rok}$, a stopień ochrony przed korozją kształtował się na poziomie 98,8\%. W przypadku środka komercyjnego A szybkość korozji testowych płytek Steel Shimstock wynosiła $0,025 \mathrm{~mm} / \mathrm{rok}$, a stopień ochrony przed korozją znajdował się na poziomie $98,03 \%$.

Wykonano badania właściwości przeciwkorozyjnych oleju ochronnego PachemOO-4018 w wilgotnej atmosferze, w temperaturze $50^{\circ} \mathrm{C}$, w porównaniu do oleju komercyjnego B. Badania wykazały, że w przypadku oleju ochronnego Pachem-OO-4018, pierwsze oznaki korozji pojawiły się po 768 godzi-

komercyjnego A po 30 minutach odstawania zaobserwowano wydzielenie się 3 faz: środka komercyjnego A w ilości $10 \%(v / v)$, emulsji w ilości $50 \%(v / v)$ oraz $40 \%(v / v)$ wody.

\section{Olej ochronny Pachem-OO-4018}

Przeprowadzono badania laboratoryjne właściwości fizykochemicznych i funkcjonalnych innowacyjnego produktu - oleju ochronnego Pachem-OO-4018, opracowanego w Instytucie Nafty i Gazu - Państwowym Instytucie Badawczym, we współpracy z firmą Pachemtech, w ramach projektu Innowacyjne środki chemiczne z udziałem zmodyfikowanej imidazoliny dla przemystu rafineryjnego, wydobywczego ropy naftowej, hutniczego i maszynowego.

Przeprowadzone badania wykazały bardzo dobre właściwości fizykochemiczne i funkcjonalne oleju ochronnego Pachem-OO-4018. Badany olej charakteryzuje się niską lepkością, około $5 \mathrm{~mm}^{2} / \mathrm{s} \mathrm{w}$ temperaturze $40^{\circ} \mathrm{C}$, temperaturą zapłonu powyżej $100^{\circ} \mathrm{C}$ oraz niską temperaturą płynięcia - poniżej $-40^{\circ} \mathrm{C}$. Badany olej na powierzchni metalu tworzy cienką, o grubości $2 \mu \mathrm{m}$, miękkopowłokową warstwę ochronną o wysokiej trwałości w czasie oraz o wysokiej zdolności wypierania wilgoci i wody. nach, dla oleju komercyjnego B po 672 godzinach, a dla próbki zerowej po 6 godzinach.

Przeprowadzono badania właściwości ochronnych oleju Pachem-OO-4018 przed działaniem jonów chlorkowych $\mathrm{Cl}^{-}$ metodą emulsyjną na płytkach ze stali, z miedzi, z brązu cynowo-cynkowo-ołowianego i z brązu aluminiowego. Badania wykazały, że wygląd płytek po badaniu w porównaniu z wzorcowymi płytkami świeżo polerowanymi nie zmienił się. Powierzchnie płytek nie pociemniały i nie stwierdzono ognisk korozyjnych.

Wykonano badanie właściwości deemulgujących oleju ochronnego Pachem-OO-4018 w porównaniu do oleju komercyjnego B. Badania wykazały, że zarówno w przypadku oleju ochronnego Pachem-OO-4018, jak i oleju komercyjnego B proces deemulgowania przebiega szybko i do 15 minut następuje rozdzielenie na dwie czyste fazy: olej i wodę, brak jest międzyfazy.

Olej ochronny Pachem-OO-4018 może być stosowany do ochrony czasowej przed korozją atmosferyczną powierzchni wyrobów metalowych, w tym łożysk tocznych, podczas ich składowania, transportu i użytkowania, w zależności od warunków składowania, od 8 do 15 miesięcy. 
Artykuł powstał na podstawie projektu pt.: Innowacyjne środki chemiczne z udziałem zmodyfikowanej imidazoliny dla przemystu rafineryjnego, wydobywczego ropy naftowej, hutniczego i maszynowego - projekt dofinansowany ze środków NCBiR W ramach Programu Badań Stosowanych - Ścieżka A; umowa nr PBS/3/A1/15/2015.

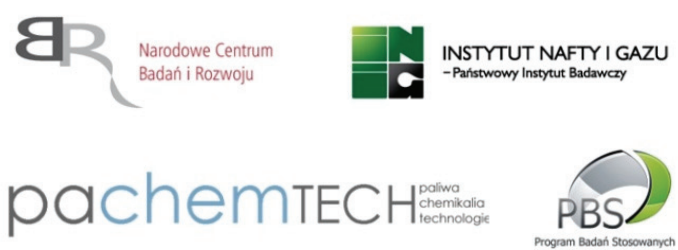

\section{Literatura}

Antosz A., Ptak S., 2017. Ciecze stosowane do obróbki plastycznej blach stalowych na zimno. Nafta-Gaz, 2: 126-132. DOI: 10.18668/ NG.2017.02.08.

Awad S.B., 2004. Aqueous ultrasonic cleaning and corrosion protection of steel components. Metal Finishing, 102: 56-61. DOI: 10.1016/ S0026-0576(04)84676-2.

Bart J.C.J., Gucciardi E., Cavallaro S., 2013. Formulating lubricating oils. W: Biolubricants (s. 351-395). Woodhead Publishing Limited, Oxford-Cambridge-Philadelphia-New Delhi.

Baszkiewicz J., Kamiński M., 2006. Korozja materiałów. OWPW, Warszawa: 9-13, 152-153.

El Ibrahimi B., Jmiai A., Bazzi L., El Issami S., 2017. Amino acids and their derivatives as corrosion inhibitors for metals and alloys. Arabian Journal of Chemistry, dostępne on-line, DOI: 10.1016/j. arabjc.2017.07.013.

Gaździk B., 2016. Procesy korozyjne w rafineriach i zapobieganie ich skutkom poprzez stosowanie inhibitorów korozji. Nafta-Gaz, 3: 198-206. DOI: 10.18668/NG.2016.03.07.

Hassan M.M., Barker H., Collie S., 2015. Enhanced corrosion inhibition of mild steel by cross-linked lanolin-coatings. Progress in Organic Coatings, 78: 249-255. DOI: 10.1016/j.porgcoat.2014.08.012.

Hunter L.R., Paul W.F., 2004. Cleaning of precision space assemblies. Metal Finishing, 102: 50-54.

Steinmec F., Łapa M., Szczurek T., 1984. Rozwój krajowych środków ochrony czasowej metali. Akorinol i Akorin. Konferencja Koninki.

Surowska B., 2002. Wybrane zagadnienia z korozji i ochrony przed korozją. Wydawnictwo Politechniki Lubelskiej, Lublin: 75-112.

Tate T.N., Beale E.W., 2010. Temporary Protectives. W: B. Cottis, M. Graham, R. Lindsay et al. (eds.), Shreir's Corrosion (vol. 4, s. 2678-2682). Elsevier.

TOTAL Polska, 2003. Przemysłowe środki smarne. TOTAL Polska Sp. z o.o., Warszawa: rozdział 16, rozdział 20.

Zawadzki J., 1962. Konserwacja i opakowania wyrobów metalowych. WNT, Warszawa: rozdział 4: 86-123, rozdział 5: 126-155.

Zawadzki J., 1969. Ochrona czasowa metali. WNT, Warszawa: rozdział 5: 114-136.

Zhang F., Ju P., Pan M., Zhang D., Huang Y., Li G., Li X., 2018. Self-healing mechanisms in smart protective coatings: A review. Corrosion Science, 144: 74-88. DOI: 10.1016/j.corsci.2018.08.005.

Zhu Y., Free M.L., Woollam R., Durnie W., 2017. A review of surfactants as corrosion inhibitors and associated modeling. Progress in Materials Science, 90: 159-223. DOI: 10.1016/j. pmatsci.2017.07.006.

Żabicki D., 2012. Czasowa ochrona przed korozją. Magazyn Przemysłowy. <https://www.magazynprzemyslowy.pl/produkcja/ Czasowa-ochrona-przed-korozja,2774,1> (dostęp: 28.09.2018).

\section{Patenty}

Patent PL 134565 Sposób wytwarzania suchopowłokowego środka do ochrony czasowej metali przed korozją, 1983.

Patent PL 232455 Rozpuszczalnik do czyszczenia produktów ze stali precyzyjnej, zwłaszcza łożysk kulkowych, 1983.

Patent PL 262934 Inhibitor korozji przeznaczony do zabezpieczenia powierzchni oczyszczanych metodami „na mokro”, 1988.

Patent US 3441419 Process for cleaning and corrosion protection of metals and a composition therefor, 1969.

Patent US 5665172 Method for washing an article with composition having a brominated hydrocarbon and stabilizer, 1997.

Patent US 5858953 Stabilized 1-bromopropane composition, 1999.

Patent US 5690862 No flash point solvent system containing normal propyl bromide, 1997.

Patent PL 133639 Środek do ochrony czasowej metali przed korozją, 1985.

Patent CA1258161 Corrosion-inhibiting composition for metal preservative oils, 1989

Patent CN 102344848 Bearing anti-corrosive oil composition, 2013.

Patent CN 105441167 Anti-oxidation and anti-corrosive lubricating oil, 2016.

Patent RU 2184769 Protective additive for preservative lube oils and preservative lube oil containing it, 2002.

Patent US 3383328 Water displacing and rust preventive compositions, 1968.

Patent US 3897349 Anti-rust additive composition, 1975.

Patent US 3981682 Corrosion inhibiting compositions and process for inhibiting corrosion of metals, 1976.

Patent US 20160230078 Anti-corrosion formulations with storage stability, 2016.

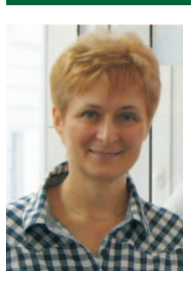

Mgr inż. Barbara GAŹDZIK

Starszy specjalista badawczo-techniczny w Zakładzie

Olejów i Środków Smarowych i Asfaltów

Instytut Nafty i Gazu - Państwowy Instytut Badawczy ul. Lubicz 25 A

31-503 Kraków

E-mail: barbara.gazdzik@inig.pl

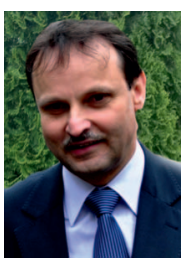

Dr inż. Roman KEMPIŃSKI

Dyrektor Naczelny

Pachemtech Sp. z o.o.

ul. Kobiałka $7 \mathrm{a}$

09-411 Płock

E-mail:Roman.Kempinski@pachemtech.eu

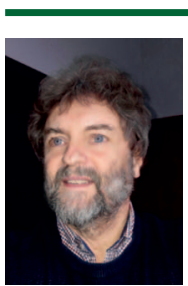

Mgr inż. Zbigniew PAĆKOWSKI

Dyrektor ds. Technicznych

Pachemtech Sp z o.o.

09-411 Płock, ul Kobiałka 7a

E-mail:Zbigniew.Packowski@pachemtech.eu

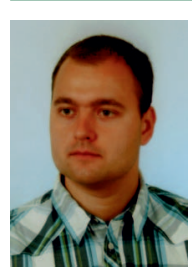

Mgr inż. Kamil POMYKAŁA

Specjalista inżynieryjno-techniczny w Zakładzie

Olejów, Środków Smarowych i Asfaltów

Instytut Nafty i Gazu - Państwowy Instytut Badawczy

ul. Lubicz 25 A

31-503 Kraków

E-mail: kamil.pomykala@inig.pl 